\title{
KERATITIS SICCA
}

BY

W. S. Duke-Elder

LONDON

THE occurrence of a dystrophy of the cornea associated with a deficiency of lacrimal secretion appears not to be of very common occurrence. The fact, however, that a number of cases have appeared in the literature showing a similar or a related clinical picture, suggests that such a condition should be recognized as a well-defined clinical entity.

The following case seems illustrative of the condition. A child, aged five and a half years, appeared at the out-patient's department at Moorfields Hospital complaining of chronic photophobia. The boy was one of a family of three, the others of which were in every respect normal. 'The child himself was perfectly developed mentally and physically, except that his mother gave a history of complete absence of tears since birth. She gave a history also of the presence of a viscous sticky secretion on the lids when the child was very young, but which for the past year or two had not been evident. It appeared that the child had never wept, although he was accustomed to rub his eyes continually, and, when crying, complained of pain over them. The photophobia appeared to have been very marked indeed during the first two or three years of life, but was now less disturbing. Examination showed that, apart from the condition of the corneae, his eyes were normal, with good vision (6/9 with correcting glasses) and with normal corneal sensation. Situated in the deeper layers of the epithelium and in a few instances involving the superficial part of the substantia propria there were considerable numbers of punctate opacities of each cornea; some of them were large and diffuse, while others were small and discrete. They were more numerous in the lower segment of the cornea, where they were interspersed with a few short tenuous linear opacities. The child's eyes were dry, and the secretion of tears as measured by Schirmer's blotting paper test (1903) gave a subnormal result, while their reflex stimulation by strongly smelling substances was similarly subnormal, although subjective evidences of discomfort during this test were by no means lacking.

I have been able to trace three other cases of congenital absence or deficiency of lacrimal secretion in the literature (Coppez, 1920; Kayser, 1921 ; and Ishikawa, 1928). In the first of these three there were other congenital deformities associated with the eyes (epicanthus and ptosis), and it was assumed that the lacrimal gland was either hypoplastic or absent; the conjunctiva, however, was 
relatively normal and the cornea was clear. Ishikawa's was of a somewhat similar nature, although no other congenital deformities were present : there was much photophobia, blinking was frequent, and although the conjunctiva was hyperaemic, the cornea appeared

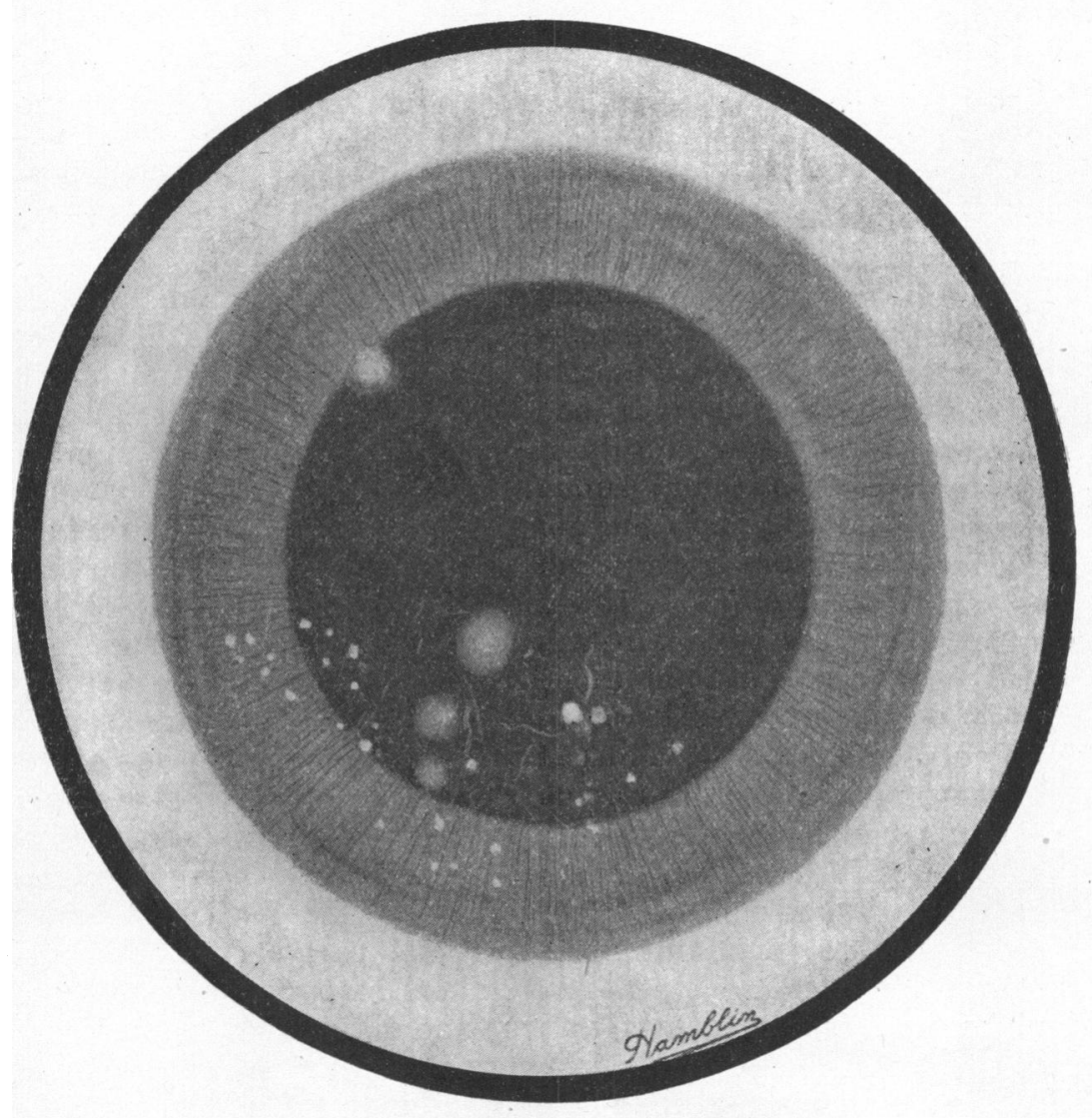

again to be normal. Kayser's case was somewhat anomalous, for the condition was aocompanied by a congenital trigeminal palsy which appeared to be of central origin. The cornea was insensitive, and was scattered over with infiltrated opacities, which eventually broke down and led to a perforation with a prolapse of the iris and the development of a hypopyon ulcer. It is probable that the changes in this last case were largely due to "neuropathic" influences (whatever that may mean); and consequently the literature appears to contain no uncomplicated instance of the congenital occurrence of a lacrimal deficiency giving rise to a keratitis as appears to have occurred in the present case. 
There are, however, several cases of a lack of lacrimal secretion developing after birth which appear to bear a very close analogy to the present one. Cases of such a nature which have been reported in the literature may be divided into two groups.

1. The first to draw attention to such a picture in the cornea was Wagenmann (1893-1902), who reported two cases resulting from injury. The first was a case of a fracture of the base of the skull which was followed by a failure of the secretion of tears, uncomplicated by a trigeminal paralysis. The second followed an excision of the lacrimal gland undertaken on account of suppuration. The corneae showed opacities having a punctate distribution which were associated with filaments and with thickenings and indentations of the epithelium. Avizonis (1928) reported a somewhat similar filamentous condition after operative removal of the lacrimal gland. Engelking (1928) reported two similar cases : in one, the lacrimal gland was removed for a cirrhotic tuberculous condition, with the result that a typical filiform keratitis developed almost immediately; the second case was less typical. An operation for empyema of the frontal sinus was followed by ptosis, a lack of the upward movement of the globe, and very severe pain. The severity of the pain led to procedures being undertaken for the destruction of the first division of the trigeminal nerve, and five years later to excision of the Gasserian ganglion. This was followed by complete insensitivity of the cornea and cessation of lacrimation, the clinical picture showing numerous punctate defects and a large central ulcer but no filaments.

2. The second group of cases has been reported occurring spontaneously in women after the period of the climacteric (A. Fuchs, 1919 ; Schöninger, 1924 ; Scheerer, 1928 ; Betsch, 1928; Ishikowitz, 1928). In most of these cases a failure of lacrimal secretion involving dryness of the eyes and accompanied by more or less marked photophobia had been evident for some years, commencing after menstruation had ceased. In many of them a somewhat similar defect in secretion involved the salivary glands of the mouth and the sweat glands of the skin. The usual clinical picture was that of a chronic conjunctivitis showing velvety papillae, and characterized by a tenacious secretion containing epithelial cells, while in the cornea punctate opacities and sometimes filaments were evident, limited especially to the lower periphery. In one or two cases, also, a periodic swelling of the parotid gland had been noted.

It would seem, therefore, that such a keratitis associated with punctiform opacities, sometimes with filaments, and usually accompanied by a chronic conjunctivitis characterised by a small amount of viscous secretion, can be definitely associated with the lack of tears, no matter in what manner this deficiency of secretion is brought about, whether $(a) \cdot$ congenitally, $(b)$ after trauma or 
operation, or $(c)$ spontaneously in women after the period of the climacteric. This would seem to indicate that the mucous secretion of the conjunctiva is not sufficient to keep it adequately lubricated ; and the series of cases reported by Avizonis (1928), wherein prolonged kerato-conjunctival irritation followed an excision of the upper fornix, seems to bear out the fact that such an operation (e.g., in trachoma), or a removal of the lacrimal gland in epiphora cannot always be undertaken with impunity. In addition to the lack of tears the occasional association of this condition with paralysis of the trigeminal nerve, and its frequent association with deficiency or dysfunction of the endocrine glands is of interest.

It is noteworthy that the keratitis is frequently associated with the presence of epithelial filaments; but again it is to be remembered that this is not invariably the case. In the present case none were evident, but this does not exclude the possibility of their having been present at an early period when a tenacious and viscid secretion seems to have been a pronounced feature. In any case it is probably best to regard the formation of filaments as a secondary result of the epithelial lesion. Recent continental authors in describing the condition have referred to it merely as a "filamentary keratitis"; but in addition to the fact that filaments are probably an incidental rather than an essential feature of the disease, this term is applicable to many other conditions, occurring after abrasions, wounds, and herpes of the cornea, and in absolute glaucoma, while it appears to be definitely associated with arthritic conditions, especially those which are presumably of polyglandular aetiology. These have been recently annotated by Houwer (1928), and it is interesting that in one of the cases of the present series (Isikowitz), the patient was a woman of fifty-three years of age who showed a typical picture of filiform keratitis, and had, in addition to a complete absence of lacrimal secretion, an arthritis of both hands and feet which was attributed to an endocrine origin. It is probable that these cases are nearly related to those of group II above. For these reasons it seems preferable to regard the condition associated with a deficiency of lacrimal secretion as a clinical entity, and, rather than give it a name descriptive of one of its clinical characteristics (which may not be an invariable feature, and certainly is not a distinctive one), to refer to it in terms of what appears to be the most important factor in its aetiology-keratitis sicca.

As this paper is in press a second case (aged 4 years) of congenital absence of the lacrimal gland with lack of tears h"s come under my notice through the courtesy of Mr. H. D. Gillies. There was a chronic conjunctivitis with velvety papillae and a viscid secretion, but the cornea appeared normal although slit-lamp examination was impossible. The case was complicated by marked ptosis and epicanthus with a failure in the development of the derivatives of the medial nasal process. It therefore comes into line with the case of Coppez, and forms the fifth case of this condition. It may be that the immunity of the cornea in this case (as in that of Coppez) was due to protection by the ptosis. 


\title{
BIBLIOGRAPHY
}

Avizonis, P.-Ueber schädliche Folgen der Tränendrüsenentfernung, Ber. vers. deutsch. ophthal. Ges., Heidelberg, S. 341, 1928.

Betsch, A.-Die chronische Keratitis filiformis als Folge mangelnder Tränensekretion. Klin. Monatsbl. f. Augenheilk., Bd. LXXX, S. 618, 1928.

Coppez. - Un cas d'absence congénitale de la secretion lacrymale. Rev. gén. d'Ophtal., T. 341, 1920.

Engelking, E.-Ueber Hornhaut und Bindehautveränderungen infolge mangelnder Tränensekretion. Klin. Monatsbl.f. Augenheilk., Bd. LXXXI, S. 75, 1928.

Fuchs, A.-Funktionstörung der Speichel und Tränendrüsen. Ophthal. Ges., Wien, 1919.

Houwer, M. - Keratitis filamentosa and chronic arthritis: Trans. Ophthal. Soc. U.K., Vol. XLVII, p. 88, 1927.

Klin. Monatsbl. f. Augenheilk., Bd. LXXX, S. 10, 1928.

Ishikawa, F.-Mangelhafte Tränensekretion als angeborene Anomalie. Klin. Monatsbl. f. Augenheilk., Bd. LXXX, S. 792, 1928.

Isikowitz, J.-Die endocrine Periarthritis (Umber) und Keratitis filiformis. Klin. Monatsbl. f. Augenheilk., Bd. LXXXI, S. 85, 1928.

Kayser.- Ein Fall von angeborener Trigeminuslähmung und angeborenen totalen

Tränenmangel. Klin. Monatsbl. f. Augenheilk., Bd. LXVI, S. 652, 1921.
Scheerer.-Aussprache. z. Vortg. Avizonis. Ber. deutsch. ophthal. Ges., Heidelberg, S. 304, 1928.

Schirmer.-Studien zur Physiologie und Pathologie der Tränenabsonderung und Tränenabfuhr. Arch.f. Ophthal., Bd. LVI., S. 253, 1903.

Schöninger.-Ueber Keratitis filiformis bei Hypofunktion der Tränendrüsen. Klin. Monatsbl. f. Augenheilk., Bd. LXXIII, S. 208, 1924.

Wagenmann.-Ber. vers. ophthal. Ges., Heidelberg, S. 172, 1893.

Einiges ueber die Erkrankung der Tränenorgane besonders auch der Tränendrüsen. Münch. med. Wochenschr., Bd. XVI, S. 682, 1902.

\section{HAEMANGIOMA OF THE ORBIT}

\author{
BY
}

\section{J. BRUCe Hamilton}

SENIOR HOUSE SURGEON, ROYAL LONDON OPHTHALMIC HOSPITAL

M. H., female, single, aged 40 years, an English school-teacher, was admitted as an in-patient to the Royal London Ophthalmic Hospital on June 21, 1929, and gave the following clear history :-

Five years ago while in South Africa she noticed that her left vision was blurred and she at once consulted an oculist in Durban who advised dental treatment which was carried out. Despite treatment the sight of the left eye gradually deteriorated, so last year while in New Zealand she again saw an eye specialist who said she had scleritis and changed her glasses. This year her vision became so bad that she returned to England for further advice. Her general health has always been good.

On Examination :- There was a fairly extensive capillary naevus of the left side of the face, a portion of which is shown in Fig. 1. 